\title{
"Unlike their Playmates of Civilization, the Indian Children's Recreation must be Cultivated and Developed": The Administration of Physical Education at Pelican Lake Indian Residential School, 1926-1944
}

\author{
Braden Paora Te Hiwi \\ Lakehead University
}

\begin{abstract}
A large body of literature about the residential school system has helped to promote a national awareness and discourse on the issue, but relatively little is known about physical education within that system. This article traces the administrative intent and implementation of physical education - namely sport, exercise, and recreation - at Pelican Lake Indian Residential School from 1926 to 1944 . The concept of "citizenship education" was used to focus this study on the ways in which school administrators sought to civilize the students by developing particular ideals of citizenship. Administrators attempted to use physical education as a means to impart character traits, such as self-discipline and good sportspersonship, along with the desire to promote "civilized" ideas about healthy activity. Seemingly trivial elements of residential school life, such as ball games or running races, were part of a broader Indian policy vision that sought the cultural, and, ultimately, the political, assimilation of Indigenous peoples.
\end{abstract}

\section{RÉSUMÉ}

Plusieurs études sur les pensionnats autochtones ont contribué au développement d'une conscience et d'un discours national sur cette question, mais on connait toutefois relativement peu de chose au sujet de l'éducation physique dans le système. Cet article examine l'intention administrative et la mise en place de l'éducation physique-à savoir le sport, l'exercice et les loisirs - au pensionnat indien de Pelican Lake entre 1926 et 1944. Le concept "d'éducation à la citoyenneté " a été utilisé afin de centrer cette étude sur la façon dont les administrateurs du pensionnat ont cherché à civiliser les élèves en développant des modèles particuliers de citoyenneté. Les administrateurs ont cherché à utiliser l'éducation physique comme un moyen de transmettre des traits de caractère, tels que l'autodiscipline et l'esprit sportif, ainsi que le désir de promouvoir des idées " civilisées " sur les saines habitudes. Ainsi, des éléments de la vie au pensionnat en apparence sans importance, tels que les parties de ballon ou les courses, ont fait partie d'une vision plus large de la politique indienne visant l'assimilation culturelle, puis éventuellement, l'assimilation politique des peuples autochtones. 


\section{Introduction}

In December 2015, the work of the Truth and Reconciliation Commission (TRC) of Canada culminated in the release of its extensive, multiple-volume report. ${ }^{1}$ The TRC was established seven years before the report's release with a mandate to investigate and record histories of the residential school system. The dominant narrative of students' experiences, as the TRC's report highlights, includes profound cultural loss, physical, psychological, and sexual abuse, and death and disease, among other destructive legacies that resulted from the actions of church and state in the administration of these schools. ${ }^{2}$ The intent of the commission is to use the histories of the residential school system to facilitate reconciliation in the relationship between Indigenous and non-Indigenous peoples. The summary report of the TRC cites Phil Fontaine, former national chief of the Assembly of First Nations and a residential school survivor himself, who, when addressing the Senate of Canada connected the idea of reconciliation to a notion of citizenship: "Reconciliation then, implies a solemn duty to act, a responsibility to engage, and an obligation to fulfill the promises inherent in an advanced democratic and ethical citizenship." ${ }^{3}$ In what ways did the residential school system shape the citizenship of its students? And would our understanding of this history, as Fontaine contends, have implications for the future of Canadian citizenship for Indigenous peoples? Only a limited body of research on residential schools has examined the role of citizenship in the education of its students. By looking at the administration of physical activities at the Anglican-run Pelican Lake Indian Residential School, this article helps to develop this literature by examining the role of physical education in promoting citizenship in the students.

The residential school system was a national education program for Indigenous youth. Its primary goals, however, were not academic; the disastrously poor advancement of the students through the curriculum can attest to the utter failure of its classroom instruction. ${ }^{4}$ Rather, as was the case in Indian policy more broadly in that era, its primary purpose was to legitimate, sustain, and extend colonial relations with Indigenous peoples and thereby act as a means of social, cultural, and political control. ${ }^{5}$ The system was implemented in earnest during the 1880 s, shortly after the establishment of the Indian Act (1876), through a partnership between Christian churches and the federal government; the latter provided the mandate and administrative infrastructure while the former operated individual schools. The system expanded through the twentieth century until the Indian Act was revised in 1951, moving Indigenous students into the provincial education system. By the 1970s, most residential schools had been closed. The federal government's intentions for the residential school system were justified by the racist assumption that Indigenous cultures were inferior. ${ }^{6}$ This overarching colonial mentality rationalized a number of damaging policies associated with the schools including the forced removal of children from their families and communities, ${ }^{7}$ malnourishing diets, ${ }^{8}$ an absence of love and care for the students, ${ }^{9}$ the abusive nature of its strict discipline, ${ }^{10}$ and the harsh (and often brutal) punishments. ${ }^{11}$

My primary aim in this paper is to use the history of physical education at the 
Pelican Lake Indian Residential School to contribute to two broader discussions: first, to identify the policy of physical education in the residential school system; second, to explore the relationship between physical education and citizenship education in the residential school system during the first half of the twentieth century. ${ }^{12}$ In order to investigate the official policy position of physical education across the country and to understand how local school administrators at the Pelican Lake school implemented physical education, I examined archival documentation from the federal government and the Anglican church. ${ }^{13} \mathrm{~J}$. R. Miller suggests that "education for citizenship" in a liberal democracy was the educational thrust in residential schools after World War II because it was widely recognized that the primary function of the school system was to "turn out good citizens." ${ }^{14}$ There is a dearth of research, however, that uses citizenship as a lens through which to analyze the residential school system. ${ }^{15}$ My intent in this article is to trace how citizenship education was used until the 1940s, with a focus on how this was envisioned through physical development. Questions remain about what "good citizenship" in residential schools meant, how citizenship was promoted and implemented, and how it changed over time.

In laying out how physical education and citizenship were linked at Pelican Lake, this article begins with a broad discussion of how residential schools were an important pillar of Canada's policy for fostering a culture of citizenship in Indigenous peoples. Next, through the examination of the policy statements made by Indian Affairs and the Indian and Eskimo Residential School Committee (hereafter referred to as the committee), the Anglican body responsible for administering its residential schools, I outline how physical education was envisioned as part of the broader citizenship agenda. From here, I turn to the history of Pelican Lake Indian Residential School and the First Nations students who attended it. Administrators at Pelican Lake used physical activities in ways consistent with the citizenship education goals promoted by Indian Affairs and the committee nationally. This included a focus on forming healthy habits and developing a Euro-Canadian character. The implementation of physical education by staff at the Pelican Lake school was limited, however, thus highlighting the discrepancy between official policy and its implementation at the school. Many of the limitations of the residential school system, including a lack of resources, resulted in a shortage of trained instructors, facilities, and equipment, which shaped a restricted program of physical education at the Pelican Lake school.

\section{Indian Policy, Citizenship Education, Physical Education and the Residential School System}

When the province of Canada passed the Act to Encourage the Gradual Civilization of the Indian Tribes in the Province, and to amend the laws respecting Indians in 1857, it legislated an assimilationist agenda. The Act also put into place the legal mechanism for enfranchisement, which would replace an individual's status as an "Indian" with British citizenship. In 1876, this policy was absorbed into the new Indian Act, which defined an Indian as someone who needed to earn citizenship after successfully proving competency in speaking English, attaining a basic level of 
education, and having good moral character, as determined by a local panel of adjudicators that would include Indian Affairs officials and local missionaries. ${ }^{16}$ Indian Affairs defined "Indian" in contradistinction to an ideal "citizen." While Indian Affairs defined a "citizen" as someone who was free, independent, and capable of managing their own affairs, an "Indian" was understood by Indian Affairs to be a ward of the state and in need of government paternalism. ${ }^{17}$ Indian Affairs saw enfranchisement as the ultimate objective and successful conclusion of its civilization policy for Indigenous peoples and the residential school system was a cornerstone of its efforts to achieve that goal. ${ }^{18}$ Until the enfranchisement policy was abandoned in 1961, Indian Affairs viewed the development of citizenship for Indigenous peoples as involving two main types of assimilation: first, cultural assimilation sought to terminate and replace Indigenous cultures by imposing Euro-Canadian culture on them; and second, political assimilation would remove the now-enfranchised peoples from their Indigenous communities and absorb them into the country as a member of the Canadian state. ${ }^{19}$ This thread of ideas provided the conceptual basis for the promotion of citizenship by Indian Affairs and shaped the rhetoric of official policy. ${ }^{20}$

Citizenship education is the set of ideas that guides the process of social, moral, political, and physical regulation and production, in which specific understandings of what it means to be a desirable subject of the state are pursued and developed in a student population. ${ }^{21}$ Through the residential school system, Indian Affairs and the committee attempted to impart a diverse but coherent set of desired traits to the boys and girls under their control, ${ }^{22}$ traits deemed inherent to the logic of civilization used to transform a ward into a citizen. ${ }^{23}$ Training for citizenship provided the foundation necessary to apply for citizenship through the enfranchisement policy. Some of the character traits that Indian Affairs and the committee desired to promote in the school system included discipline, health and hygiene, Christian morals, EuroCanadian social mores, and individuals' responsibility for themselves. ${ }^{24}$

At the end of the nineteenth century, the development of good character was an important component of the physical education curriculum in Canada. The first superintendent of education in Upper Canada, Egerton Ryerson, crafted the purpose of physical education. Anchored in the nineteenth-century notion of muscular Christianity, he envisioned a curriculum that developed the physical, social, intellectual, and moral dimensions of the self. ${ }^{25}$ Fostered in Britain, the ideas underpinning muscular Christianity focused on the development of good Christians through sport and games by instilling character traits such as courage, toughness, self-reliance, team spirit, and sportsmanship. ${ }^{26}$ The virtues a student developed on the field, like courage, were understood to be transferable to contexts off the sports field, such as in work, social, and political life. ${ }^{27}$

The extent to which physical education was implemented in residential schools, how it was implemented, the effects it had on students, and how it developed over time is not well understood. However, the literature provides a good outline of the major elements - the activities and purposes - of physical education programs in residential schools. Individual school administrators' use of physical education in the first half of the twentieth century was ad hoc and poorly supported by Indian Affairs; 
nevertheless drill, calisthenics, gymnastics, exercises, mass displays, games, and some sports featured in the education of residential school students. ${ }^{28}$ These were many of the same activities that were used in the provincial education systems throughout Canada. ${ }^{29}$ In 1950, Indian Affairs appointed its first bureaucrat specifically assigned to guide sport and recreation, which has previously been noted by scholars as marking the beginning of physical education policy in residential schools; ${ }^{30} \mathrm{I}$ argue here, however, that a coherent set of ideas to guide the administration of physical education was in operation throughout the residential school system prior to that time. In particular, physical education was important to Indian Affairs because of the way in which the activities, if "properly administered," were thought to instil obedience and discipline, inculcate Euro-Canadian norms, foster "civilized" ideas about health, reinforce gender-appropriate roles, and teach ideals of good citizenship. ${ }^{31}$

\section{Physical Education Policy in the Residential School System, 1926-1944}

Indian Affairs and the committee operated from the understanding that Indigenous peoples were savage, uncivilized, and thus, among other deficiencies, incapable of knowing how to make good use of their leisure time. ${ }^{32}$ Therefore, physical activity had to be purposeful and accompanied by proper instruction. ${ }^{33} \mathrm{~A}$ distinguishing feature of the paternalism embedded in teaching physical education to Indigenous students was that school administrators used rigid forms of organization and supervision to direct activities. All the recreational activities were popular Euro-Canadian activities. Traditional Indigenous games, sports, and physical activities were incongruent with the assimilation and civilization agenda of Indian Affairs. ${ }^{34}$

In its 1926 Annual Report, Indian Affairs stated clearly that the intended curriculum for its schools was to "adopt the course of studies for the province in which they are situate $[s i c]$. Emphasis is placed on the subjects of language, reading, domestic science, manual training, agriculture and physical training." ${ }^{35}$ Residential school staff encouraged various types of physical activities, including calisthenics, exercise, drill, and breathing exercises, as well as sports, games, and other recreational activities. In 1938, Indian Affairs reported on the expanding variety of opportunities for labourer skills that were positioned alongside physical activities in building a comprehensive plan for physical development in the students. ${ }^{36}$ The focus on physical training was part of a holistic approach to a student's transformation: Indian Affairs and the committee sought to improve "the physical, intellectual and moral fibre of the Indian." ${ }^{7}$

The promotion of health was a key feature of Indian Affairs' and the committee's formal physical education policy statements. By the 1920s, Indian Affairs had advised teachers and principals in the use of calisthenics exercises by posting instructions on the daily registrar as an everyday reminder of its curriculum. ${ }^{38}$ The attention to detail was sometimes remarkable. Teachers were advised to "lay stress on physical activities that will strengthen the chest and neck." 39 Indian Affairs' instructions to its teachers in the daily registrar was consistent with its 1910 booklet, Calisthenics and Games, which was the department's most comprehensive set of instructions on how teachers should implement physical activities throughout the schools. ${ }^{40}$ Both the 
registrar and booklet focused on calisthenics exercises, strengthening the respiratory system, and promoting outdoor exercises and games. For instance "exercise no. 2 deep breathing" instructed students to "place the hands on the hips with the elbows well back; thumbs to the rear and fingers to the front. On the command 'Inhale,' inflate the lungs to full capacity; on the command 'Exhale,' let go the breath, forcing all out possible $[$ sic $]$. Repeat freely four to six times." ${ }^{41}$ During the 1930 s, the annual reports of Indian Affairs indicated the importance of physical education. In 1932, Indian Affairs noted that health in the residential school system "receive[d] special attention. Good medical supervision has been arranged and much thought is given to physical education, proper diet and sanitation." ${ }^{2} 2$ A few years later, in 1936, Indian Affairs continued to make the point that "a special effort [wa]s made in the matter of physical education and fairly comprehensive medical and dental supervision and treatment are provided." 43 The official policy line of Indian Affairs clearly indicated that health was an important rationale for its intent to provide physical education to residential school students.

Physical activities were intended to instil responsibility in students for care of their bodies, alongside other lessons on personal and home hygiene. Instructions to brush their teeth, sit up straight, or keep their clothes clean were the lessons in how to be a well-developed student, which teachers believed could help stem the tide of communicable disease. ${ }^{44}$ Indian Affairs and school administrators used these health lessons as part of a broader strategy for protecting health, which included medical treatment and sanatoria, healthy meal plans and nutrition, and safe and well-ventilated buildings, but these initiatives were grossly under-resourced and never effectively implemented. ${ }^{45}$ For the students, the official health policy statements were often empty and meaningless promises. The colonial rationalizations embedded within the intent to promote health were meaningful, however, for the church and state. They provided a legitimizing motivation for implementing physical education within the residential school system.

In particular, the health policies of Indian Affairs were woefully ineffective prior to World War II. Damp, dilapidated, and poorly-ventilated buildings, overcrowded dormitories, and a lack of sanitation, clean water, and food created conditions rife for communicable diseases to spread, including influenza, pneumonia, and whooping cough. ${ }^{46}$ Tuberculosis inflicted the most severe death toll; on its own, it caused as many deaths as all other causes in the residential school system combined. ${ }^{47}$ By the 1890s, the spread of tuberculosis through the residential school system had firmly taken root, which only compounded the high prevalence of tuberculosis on reserves. ${ }^{48}$ One study conducted by an Indian Affairs officer into schools on the Prairies noted the death rate of Indigenous youth was roughly ten times that of the total Canadian population. ${ }^{49}$ It was not until the middle of the twentieth century, however, that the government made any serious effort to rectify the devastating health impacts enabled by the school system. ${ }^{50}$

Character development was another priority of physical education policy in the residential school system. For example, Indian Affairs instructed teachers to use drill to set the tone for disciplined classroom work since this would "tend to procure a 
working connection between the students' and the teacher's mind and will assist in obtaining the attention and prompt discipline so necessary before real work can be commenced." " 1 The committee used sports and games to instil the muscular Christian ideal of playing the game for its own sake and not for external reward, identifying it as a necessary condition to moulding desirable character. ${ }^{52}$ The committee advised teachers to incorporate supervised play and recreation into their daily curriculum, so as to teach students how to "play the game" properly and, by extension, how to use their leisure time wisely. ${ }^{53}$ Indian Affairs wanted the education system to develop a desirable ethical framework in the students and, as such, they instructed teachers to use physical education to foster "the spirit of fair play" as part as the student's overall moral development. ${ }^{54}$ In particular, Indian Affairs believed that "running, jumping, ball games and similar sports are vitally important as a means of molding the child's character and for general exercise." 55

Lastly, redefining Indigenous understandings of gender was an important element of physical education, as it sought to reinforce Euro-Canadian gender roles. Activities for boys were to be active, vigorous, and strenuous, while girls were provided with activities that aimed to teach them to be passive, see themselves as fragile subjects, and to be cooperative rather than competitive. School administrators used gentle exercises for girls, like walking, skating, and swimming, and non-physical recreation, such as playing with dolls, whereas drill, strength, and fitness exercises and sports were usually reserved for boys. ${ }^{56}$ The pursuit of physical fitness for manual labour or the development of masculine character traits, such as courage, toughness, and a Protestant work ethic, were the intended effects of citizenship training for boys. Indian Affairs and the committee did not refer to gender in their statements to school staff and administrators about how to implement physical activities; the fervent belief in appropriate gender roles was so strongly embedded within the actions of the staff that ideas about proper male and female behaviour were simply taken for granted. ${ }^{57}$

Indian Affairs and the committee had a fairly coherent set of ideas that promoted and rationalized the use of physical activities for health promotion and character development. However, the implementation of this policy would have been somewhat ad hoc, with variation from school to school. An examination of Pelican Lake Indian Residential School provides a detailed case to explore this issue and therefore paint a fuller picture of the ways in which the national physical education policy was implemented at the local level.

\section{Pelican Lake Indian Residential School, 1926-1944}

The Anglican church and Indian Affairs sent representatives to identify a suitable location for a new Indian residential school in northwestern Ontario in 1925. The party met in the town of Sioux Lookout, Ontario located on the Canadian National Railway line approximately 400 kilometres east of Winnipeg. In spring that year, the group left Sioux Lookout by boat on Pelican Lake to assess potential locations. ${ }^{58}$ They ultimately decided on a heavily wooded 116-hectare area on the lake's shores, located approximately ten kilometres by boat from Sioux Lookout and just over three 
kilometres to a stop on the Canadian National Railway. ${ }^{59}$ By May 1926, construction on the school site had begun. The main school building would be a three-storey structure that included classrooms, two basement playrooms, a medical dispensary, a chapel, and girls' and boys' dormitories. ${ }^{60}$ The Pelican Lake school was planned to be a large Anglican institution that would, when running at capacity, operate with 125 students from Cree and Anishnaabe communities in northern Ontario.

By the summer of 1927, the Pelican Lake school was nearly complete but not yet ready to take on a full complement of students. At this time, only nine boys resided at the school. ${ }^{61}$ They were not there for classroom instruction; rather, they were there to help build and develop the school for its eventual use. ${ }^{62}$ Students served the dual purpose of making the institution more self-reliant (and therefore reducing government spending), while simultaneously providing students with the kind of manual labour training Indian Affairs intended to be their path to employment. ${ }^{63}$ The main school building was completed that year, but even then the school was not fully operational because the water system was not yet functioning. ${ }^{64}$ Nonetheless, a number of staff were now working at the school, including Reverend F. J. F. Marshall, a missionary with extensive experience working with Indigenous communities; he was soon appointed to be Pelican Lake Indian Residential School's first principal. ${ }^{65}$ Along with Principal Marshall and his wife, the Pelican Lake school had a farmer, an engineer, a general assistant, a head matron, an honorary head matron, a senior teacher, a junior teacher, a kitchen matron, a boy's supervisor, a girl's supervisor, and a laundress-seamstress. ${ }^{66}$ It was a formidable task to operate the school with such a small staff. Indeed, the students felt a lack of care and emotional support throughout the school's history, during which students' experiences were characterized by suffering, pain, and loneliness. ${ }^{67}$

By the winter of 1928 , the school was still not fully operational due to continuing delays with the water system, but the student population had grown to thirty-one, fewer than half of them girls. ${ }^{68}$ Developing and managing the physical environment was a large feature of school life. The Anglican church worked hard to level and prepare the grounds but, at this early stage, the farm was far from ready to supply the school with food. ${ }^{69}$ In 1928, when the Pelican Lake school underwent its first official inspection, the assessor, a representative of the church, commented on the lack of recreation space; "Goodness! Where do the children play?" he wrote. "What a stupendous task it will be to clear this land for cultivation." ${ }^{\prime 0}$ Clearing land and then levelling it was an ongoing task that required a great deal of male student labour. The lands would always be less than ideal for sport and recreation, since poor drainage was an ongoing issue that local administrators failed to resolve. The fields were still a problem decades later: the superintendent's report for Pelican Lake school in 1952 described the school grounds as a "morass of mud." 71 Snow covered the grounds in the winter, and the muddy fields in spring and fall made outdoor activities difficult, if not impossible.

Local school administrators worked to provide facilities and equipment for physical activities in difficult conditions. In 1928, Mrs. Marshall, the wife of Principal Marshall, requested donations of used skates from the church for the students to 
have "outdoor fun." 72 The women's association of the Anglican church played an important role in supplying additional equipment to Anglican schools, including clothing for the 811 students attending the eighteen Anglican residential schools across the country, as well as some used recreation equipment. ${ }^{73}$ Although Marshall's interest in skating predates the official opening of the school, a lack of skate blades for students remained a problem through to the late $1940 \mathrm{~s} .{ }^{74}$ From the school's beginning, the lake was important to the school's recreation program, with swimming in the summer and skating or hockey in the winter. ${ }^{75}$ Indoor play and recreation was also a feature of the school routine. There were designated play and recreation rooms in the basement of the main school building. However, rainwater kept seeping into the basement, thus curtailing indoor activities for long periods of time. ${ }^{76}$ Principal Marshall once reported that the water problem was so bad that the basement was almost like a swimming pool, which limited its use and made portions of the school a particularly dangerous place to inhabit. ${ }^{77}$ Indian Affairs had devised a policy of providing physical exercise in large and well-ventilated buildings during inclement weather. ${ }^{78}$ The lack of a safe and healthy recreation space at Pelican Lake school, as was the case in most other residential schools across Canada, shows that the idealized vision for physical education that was promoted through official policy remained disconnected from the realities of everyday school life.

The assimilationist function of the school started in earnest during the fall of 1929 , when the school was finally ready for full operation. The official opening of Pelican Lake school brought in 103 students, with the potential for more students coming to fill it to capacity. ${ }^{79}$ The children were supposed to be at least six years old and varied in age; however, children as young as two-and-a-half were admitted if officials had determined that they did not have a suitable home. ${ }^{80}$

The principals provided religious instruction as a regular part of school routine. Erasure of Indigenous spirituality was embedded in school life. Church services for students and staff were held on Mondays, Wednesdays, and Fridays at 7:00 pm, while Sundays included Sunday school in the morning and a church service in the evening. ${ }^{81}$ Two teachers instructed at the school: a junior teacher for the younger students and a senior teacher to instruct up to grade 8 . The junior students attended school from 9:00 am until 4:00 pm. Many students could only speak their traditional languages - predominantly Anishnaabe and Cree - and thus learning English became a priority. ${ }^{82}$ In the early 1930s, the vast majority of students were in grades 1 and 2. By the latter half of the 1930s, as students moved up instructional levels, some students had graduated to grades 4,5 , and 6 , although the vast majority of students were still in grades 1,2, and 3; classroom instruction was a failure that weakened future opportunities for students. ${ }^{83}$ The eradication of language was a key target for the destruction of Indigenous cultures and was a difficult experience for students. The direct erasure of Indigenous languages in the school system lasted for decades; one former student recalls the continuation of punitive efforts to wipe out Indigenous languages when another student was seen choking and gagging on soap used to wash out his mouth. ${ }^{84}$

The half day school policy used in residential schools contributed to students' 
poor education. Older students received a half day of instruction in the classroom, while the other half of the day was spent doing manual labour for the benefit of the school. The girls worked by doing the laundry, baking, working in the dairy, sewing, and keeping the dormitories clean and tidy. ${ }^{85}$ In this way, they were trained to be domestic servants and to keep house for their own families once they graduated. In the meantime, they were free labour for the school. The boys worked the farm under the supervision of the farm instructor. Their jobs included the seeding, cultivation, and harvesting of garden produce, as well as learning how to care for the horses, cattle, and pigs. ${ }^{86}$ A second important element of their work training was being a "woodsman" - "training" that, not surprisingly, involved clearing bush and removing tree stumps from the school lands. ${ }^{87}$ The boys cut and stored seventy tonnes of ice a year for cold storage and chopped and prepared over eight hundred cords of wood annually to fuel the school furnaces. ${ }^{88}$ Without a doubt, students were used as a workforce to maintain the operation of a school system that caused them so much damage. The volume of work expected from the boys did not go unnoticed. In 1945, Indian Agent Gifford Swartman suggested the amount of time they spent doing chores reduced the time available for organized sports and games, in which they were to learn important lessons in character development. He thus recommended that Pelican Lake school shift to coal as its fuel source so that more time could be spent pursuing these activities. $^{89}$

Some principals actively sought to find additional funds to enhance opportunities for physical education. In 1930, Principal Marshall received a letter from the assistant deputy and secretary at Indian Affairs informing him how to allocate funds for various items, including athletic equipment, in the school budget. ${ }^{90}$ In the following year he listed athletic equipment as a school expense in the budget he submitted to Indian Affairs. ${ }^{91}$ This was the only year he did so in the school's annual budgets from 1926 to $1932 .{ }^{92}$ The next record of a principal requisitioning athletic equipment for Pelican Lake school was in 1938, when Acting Principal Mayo asked the committee to purchase sporting equipment and uniforms. ${ }^{93}$ The committee, however, informed Mayo that he should instead charge such equipment to Indian Affairs within the regular school budget. ${ }^{94}$ These two instances of requisitions for athletic equipment suggest that the primary source for athletic equipment was through donations; otherwise physical education would have been restricted to activities that did not require additional resources. It also suggests that the principals were not fully aware of the funding system and its requirements, unless they were specifically instructed. There were no additional funds set aside for physical activities in Indian Affairs' funding system. Instead, principals had to fit physical education spending within their budgets determined by a set per capita rate, which was low and made it very difficult for them to spend their limited resources on much-needed sport and recreation supplies. ${ }^{95}$ For example, the women's association of the Anglican church provided skate blades and boots to Pelican Lake school to meet a need not filled by Indian Affairs. ${ }^{96}$ Fundraising and donations secured directly by the schools or by church groups and charitable organizations were a boon for Indian Affairs, since they enhanced the system without additional cost. 
A central philosophical justification for the use of physical education by administrators at Pelican Lake school is reported in a committee pamphlet designed to promote and attract prospective students and staff to the school. ${ }^{97}$ This document is one in a series of pamphlets designed by the committee to highlight the work being carried out in their schools. ${ }^{98}$

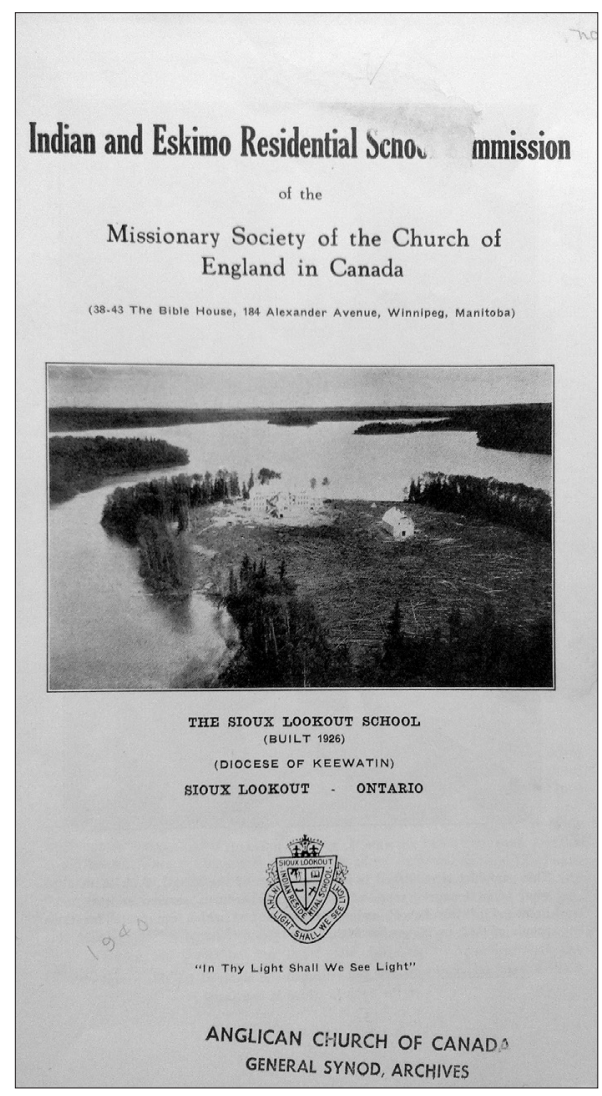

Figure 1: The Sioux Lookout School [1940], 9:8 Indian and Eskimo Residential School Commission-Reports, 1933-1941. Missionary Society of the Church of England in Canada (MSCC) fonds, GS75-103, Series 9:8, Box 131. Anglican Church of Canada/General Synod Archives, Toronto (ACC/GSA).

The pamphlet on Pelican Lake school expressed a clear vision for its recreation program:

Unlike their playmates of civilization, the Indian children's recreation must be cultivated and developed, as they lack the knowledge of creating their own amusements. Strange as it may seem, the average Indian cannot swim, so that their recreation becomes an education. Once taught, they become keen, and display good sportsmanship and courage. ${ }^{99}$

The committee and administrators at Pelican Lake school were unambiguous about the philosophy that underpinned their administration of physical education: the supposed primitivism and savagery of the school's First Nations students required 
them to receive deliberate guidance in their recreation if it was to have a civilizing effect, which would be proven by the development of important character traits typical of a good sportsperson.

Many efforts were made to implement physical education at the school, but, ultimately, they did not achieve any of the lofty philosophical goals that had been set. Prior to the 1950s, the staff at Pelican Lake school used informal games, recreation, and fitness more often than organized, competitive sport. ${ }^{100}$ Calisthenics, sack races, swimming, and skating for boys and girls were identified in the Pelican Lake school pamphlet, along with some baseball and hockey. ${ }^{101}$ The girls participated in these activities; however, more opportunities in general, and more opportunities for vigorous movements specifically, were provided for the boys. In 1951, for instance, when local school administrators finally dedicated funds to make improvements to the inadequate playgrounds of the 1940s, they went to the boys' rather than the girls' playground. ${ }^{102}$ The staff also organized hunting and fishing trips for the older boys, whose success was attributed by the committee to their "natural instincts and marksmanship." The committee reported that "a thoroughly competent instructor" led physical training at the Pelican Lake school. ${ }^{103}$ Yet, qualified instructors were hard to come by. When that reality is combined with the problem of continual staff turnover at the school, offering competent instruction was likely intermittent. In 1945, Indian Agent Gifford Swartman bemoaned the "lack of recreational opportunities [as] very noticeable" and went on to note that "under proper supervision this would go a long way toward developing character and physique." 104 The fitness, character, and health benefits of physical education failed to materialize in a significant way.

According to the committee, health was an important focus at the Pelican Lake school. The committee noted that close attention was paid to children's health, which included lessons in sanitation, trained nurses at the school, access to additional nurses and doctors from Sioux Lookout, first aid and sanatorium bedrooms in the school's main building, and the provision of cod liver oil daily. ${ }^{105}$ Despite its policy, the poor health of students was a significant and recurring problem. In the 1940s, a report to Dr. Percy Moore, the superintendent of medical services at Indian Affairs, attests to the ways in which the deplorable conditions endangered students:

In the former [boys' dormitory] the beds are so close that they touch at the sides. This is bad, especially where the children are as susceptible to respiratory disease and tuberculosis as are Indians. It might be possible to put up quarters outside the school for the farm employees, who at present occupy an entire upper dormitory, freeing this space for pupils. Alternatively, double decker beds 18 " to 2 feet apart would be better from a droplet-infection standpoint. Until something permanent can be done, the pupils should sleep head to foot alternately. I do not wish to be over-critical, but from the standpoint of public health the designation of a couple of three-bed rooms in Indian schools as preventoria is a travesty; if the entire residential school is not a preventorium what are we spending our money for? ${ }^{106}$ 
Furthermore, former student Richard Cromarty recalls that students simply had to live through measles, sores, and bedbugs because a doctor never visited the school, nor did students receive dental care until the local Sioux Lookout Indian Hospital opened in the early 1950s. ${ }^{107}$ No wonder pain and disease was rife.

In 1937, Principal Mayo described the school as being overtaken by an "epidemic" of "colds and coughs" in which 109 of 121 students were affected, ${ }^{108}$ as well as a few cases of pneumonia and several cases of whooping cough and chickenpox. ${ }^{109}$ Disease spread easily through the school. Mayo oversaw the inoculation of the students, which he hoped would ward off further losses, ${ }^{110}$ but that same year he dismissed two students from the school because they were considered incurable, ${ }^{111}$ and two other young girls died of pulmonary pneumonia, with tuberculosis, whooping cough, and chickenpox cited as contributing factors. ${ }^{112}$ In December 1937, another young boy became seriously ill; he passed away of tubercular meningitis early in $1938 .{ }^{113}$ On and on go the reports: death and disease continued to be a scourge for students at Pelican Lake school until at least $1944 .{ }^{114}$ The lack of opportunities for the physical and mental health benefits of physical activity, such as enhanced immunological response to infectious diseases, would have had a limited impact on reducing the rate and burden of these diseases. The poor program of physical education was just one of many health-related policies that were founded in good intentions and sound reasoning when penned by bureaucrats in Ottawa. But when these policies are contextualized within the actual operations of the schools, the deaths and poor health of students were not due a lack of awareness or medical knowledge by Indian Affairs or the Anglican Church, but a lack of will and ultimately a callous indifference to the plight of the students under their control.

\section{Conclusion}

The development of "civilized" health practices and building character were the primary expressions of the promotion of citizenship through physical education during the first half of the twentieth century. This policy, however, was much stronger in its vision than its implementation, at least in the case examined here. While there was political will and intention to offer physical education at the national and local levels, the Pelican Lake school administrators were restricted from doing so on many fronts, including the heavy work demands on the students' time, little support for principals, and a lack of funds for facilities, qualified instructors, and equipment. Thus the intent to assimilate and provide citizenship training for the students would have been partial at best and is consistent with the experiences of many students who could neither fit into Euro-Canadian culture nor their own traditional cultures upon leaving the residential school. ${ }^{115} \mathrm{~A}$ restricted program of physical activities was likely limited in providing physical health benefits to students, although physical activity was desperately needed in a system where death and disease were common. Furthermore, a well-resourced and better-organized system of physical activities may have promoted social and mental well-being in the students and given them an avenue to help survive their school experience, as was often the case from the 1950s onward. ${ }^{116}$ The 
health promotion function of Indian Affairs' physical education policy is just one example of a positive-sounding policy that, when examined in its full context, was undercut by other policies, best embodied in the utter inadequacy of the funding system. Ultimately, the students, their families, and their communities paid the price of government parsimony.

Although previously scholars have argued that an overt focus on citizenship in the residential school system was evident from the 1950 s onward, ${ }^{117}$ the intent to administer physical education at the Pelican Lake Indian Residential School before then fits neatly with the character and health traits deemed vital to the citizenship policy of Indian Affairs, albeit in an implicit rather than an explicit way. Physical activities such as hockey or a sack race were not trivial matters of play; physical activities were also a matter of cultural assimilation that was leveraged as a part of the development of citizenship. It was not simply a matter of cultural assimilation though, because it had important political implications in that it replaced, displaced, and marginalized Indigenous peoples' ability to define their own participation and values in physical activity. I also argue one step further, that the cultural assimilation and the political assimilation of Indigenous youth were two key elements of the same citizenship process. Thus, the intended development of the students' bodies was part of a broader policy vision that sought to eradicate Indigenous cultures in favour of a Euro-Canadian culture and to terminate Indigenous peoples' political independence and identity, replacing these with Canadian citizenship. Citizenship education is therefore useful in examining the residential school system because it attends to the issue of cultural genocide. When contextualized within the overall policy agenda of Indian Affairs, it links the function of the residential school system to the political assimilation and termination of Indigenous peoples that was the intended culmination of the Indian Affairs civilization policy.

The introduction to this paper began with an assertion made by a former national chief of the Assembly of First Nations, Phil Fontaine, in which he suggested that our understanding of the residential school system could be used as a basis for guiding action on the future of citizenship for Indigenous peoples. The imposition of colonial laws, policies, and concepts about citizenship, and the paternalistic and racist disregard of Indian Affairs and the Anglican church for Indigenous peoples' values, culture, leadership, and aspirations about physical activity, is part of the residential school history. The case presented here provides a platform and space for further thinking about how this history of physical activity could provide lessons to re-envision the promotion of citizenship. Specifically, the ways in which physical activity can be organized and developed to contribute to, legitimate, and exhibit Indigenous understandings of citizenship may offer another avenue for fostering reconciliation in Canada.

\section{Notes}

1 Truth and Reconciliation Commission of Canada (TRC), The Final Report of the Truth and Reconciliation Commission of Canada, 6 vols. (Montreal and Kingston: McGillQueen's University Press, 2015). 
Ibid.

3 TRC, Summary of the Final Report of the Truth and Reconciliation Commission of Canada (Montreal and Kingston: McGill-Queen's University Press, 2015), 217.

4 John Milloy, A National Crime: The Canadian Government and the Indian Residential School System, 1879-1986 (Winnipeg: University of Manitoba Press, 1999), 157-186.

5 See Roland Chrisjohn, Sheri Young, and Michael Maraun, The Circle Game: Shadows and Substance in the Indian Residential School Experience in Canada (Penticton, BC: Theytus Books, 2006); Mary-Ellen Kelm, Colonizing Bodies: Aboriginal Health and Healing in British Columbia, 1900-50 (Vancouver: UBC Press, 1998), 57-80; Hugh Shewell, "Enough to Keep Them Alive": Indian Welfare in Canada, 1873-1965 (Toronto: University of Toronto Press, 2004).

6 J. R. Miller, Shingwauk's Vision: A History of Native Residential Schools (Toronto: University of Toronto Press, 1996), 183-216.

7 Ward Churchill, Kill the Indian, Save the Man: The Genocidal Impact of American Indian Residential Schools (San Francisco: City Lights Books, 2004).

8 Ian Mosby, "Administering Colonial Science: Nutrition Research and Human Biomedical Experimentation in Aboriginal Communities and Residential Schools, 1942-1952," Histoire Sociale/Social History 46, no. 1 (2013): 148-153.

9 Miller, Shingwauk's Vision, 289-316.

10 Andrew Woolford, This Benevolent Experiment: Indigenous Boarding Schools, Genocide, and Redress in Canada and the United States (Winnipeg: University of Manitoba Press, 2015), 139-176.

11 Milloy, A National Crime, 138-144.

12 Janice Forsyth, "The Indian Act and the (Re)Shaping of Canadian Aboriginal Sport Practices," International Journal of Canadian Studies 35 (2007): 108-09; Janice Forsyth, "Bodies of Meaning: Sports and Games at Canadian Residential Schools," in Aboriginal Peoples and Sport in Canada: Historical Foundations and Contemporary Issues, ed. J. Forsyth and A. R. Giles (Vancouver: UBC Press, 2013), 31.

13 The primary repositories included Libraries and Archives Canada, the General Synod Archives of the Anglican church, the Shingwauk Residential Schools Centre at Algoma University, and the Sioux Lookout Museum. Student perspectives, such as those recorded in the research of the TRC, were included in this paper where possible. However, the voice of the students is limited because few records from the students' perspectives are available for the time period under study.

14 Miller, Shingwauk's Vision, 156-157, 277. For examples of the literature pointing to citizenship as a primary purpose of residential schools, see Eric Porter, "The Anglican Church and Native Education: Residential Schools and Assimilation" (PhD diss., University of Toronto, 1981), 147; Norman Gull, "The 'Indian Policy' of the Anglican Church of Canada from 1945 to the 1970s" (master's thesis, Trent University, 1992), 34; Milloy, A National Crime, 20-22. Heidi Bohaker and Franca Iacovetta, "Making Aboriginal People 'Immigrants Too': A Comparison of Citizenship Programs for Newcomers and Indigenous Peoples in Postwar Canada, 1940s-1960s," Canadian Historical Review 90, no. 3 (2009): 427-462.

15 In my research, I was only able to find three papers on this topic. See Andrea Bear Nicholas, "Citizenship Education and Aboriginal People: The Humanitarian Art of Cultural Genocide," Canadian Journal of Education 21, no. 2 (1996): 59-107; Marie Battiste and Helen Semaganis, "First Thoughts on First Nations Citizenship: Issues in Education," in Citizenship in Transformation in Canada, ed. Yvonne Hébert (Toronto: University of Toronto Press, 2002), 93-112. The focus of the two former papers is general and overarching, while Mary Jane McCallum, "To Make Good Canadians: Girl Guiding in Indian Residential Schools” (master's thesis, Trent University, 2001), examines the role of Girl Guides in training for citizenship. Through this study, I hope 
to contribute to these works by providing insight into the role of physical activities in promoting citizenship.

16 J. R. Miller, Skyscrapers Hide the Heavens (Toronto: University of Toronto Press, 2000), 140; also John Crossley quotes at length the relevant sections of the Enfranchisement Act of 1857: see "The Making of Canadian Indian Policy to 1946" (PhD diss., University of Toronto, 1987), 334-35.

17 Crossley, "Canadian Indian Policy," 210-221. Milloy quotes the perspectives of Sir John A. Macdonald, who accepted "the onerous duty of... their [the Indians] guardianship as of persons underage, incapable of the management of their own affairs." Cited in Milloy, A National Crime, 20.

18 Crossley, "Canadian Indian Policy," 223.

19 John Leslie, "Assimilation, Integration or Termination? The Development of Canadian Indian Policy, 1943-1963” (PhD diss., Carleton University, 1999), 285, 388.

20 The strong rhetoric and powerful ideological thinking behind the efforts of Indian Affairs shaped many of its policies; however, an important side note is needed to fully contextualize the complexity of the policy process. Indian policy contains many instruments and a variety of goals that were to be implemented in hundreds of communities across the country by a large bureaucracy. It therefore changed and evolved through time. Within such a complex context, the philosophical and ideological justifications of these policies often contain many inherent contradictions. At times, some policies directly conflicted with others. For example, the desire to protect Indigenous peoples by providing lands through the reserve system was a central obstacle in the government's intent to appropriate these lands for colonization. Crossley, "Canadian Indian Policy," 459-519. Furthermore, there is often a difference between the official policy line and the actual functioning of policy in its implementation. A good example is the pass system in the Canadian West. For more information, see F. Laurie Barron, "The Indian Pass System in the Canadian West, 1882-1935," Prairie Forum 13, no. 2 (1988): 35-42. From a broad perspective, perhaps the most frequent factor influencing this gap between policy and practice at Indian Affairs was the inadequate funding associated with policy implementation. Indian Affairs created many positive-sounding policies to meet their goals, but then underfunded them, undercutting their explicitly-stated objectives. The residential school system is a notoriously well-known example of this, because the underfunding did not just restrict government and church groups from achieving their goals, but doing so inflicted enormous harm on the students in the process. Dean Neu, "Accounting and Accountability Relations: Colonization, Genocide, and Canada's First Nations," Accounting, Auditing, and Accountability Journal 13, no. 3 (2000): 279-280.

21 This definition was adapted from the work of Ken Osborne, "Public Schooling and Citizenship Education in Canada," Canadian Ethnic Studies 32, no. 1 (2000), 9-10.

22 For instance, Indian Affairs advised teachers to instil an array of desirable qualities in the students, including "independence, self-respect, industry, honesty, thrift, selfmaintenance, citizenship and patriotism.” Department of Indian Affairs, Daily Register for Recording the Attendance of Indian School Pupils (Ottawa: Government Printing Bureau, 1927).

23 Developing Indigenous people as independent individuals was a central idea in the logic of civilization. Crossley, "Canadian Indian Policy," 263. Porter discusses how the transition from savage to civilized required the development of the virtues of industry, responsibility, and self-sufficiency so valued in the late nineteenth century; Porter, "The Anglican Church and Native Education," 118-119.

24 Norman Knowles, " By the Mouth of Many Messengers': Mission and Social Service in Canadian Anglicanism," in: Seeds Scattered and Sown: Studies in the History of Canadian Anglicanism, ed. Norman Knowles (Toronto: ABC Publishing, 2008), 174. Alan Hayes, Anglicans in Canada: Controversies and Identity in Historical Perspective (Urbana, IL: 
University of Illinois Press, 2004), 220-221; McCallum, "To Make Good Canadians," 3, 103 .

25 Nancy Francis and Anna Lathrop, “'Children Who Drill, Seldom Are Ill.' Drill, Movement and Sport: The Rise and Fall of a 'Female Tradition' in Ontario Elementary Physical Education - 1850s to 2000," Historical Studies in Education 23, no. 1 (2011): 64-67; Don Morrow and Kevin Wamsley, Sport in Canada: A History (Don Mills, ON: Oxford University Press, 2005), 181; Bruce Kidd, "Muscular Christianity and the Value-Centered Sport: The Legacy of Tom Brown in Canada," International Journal of the History of Sport 23, no. 5 (2006): 703; Jean Barman, "Sports and the Development of Character," in Sports in Canada, ed. Morris Mott (Mississauga, ON: Copp Clark Pitman, 1989), 234-246.

26 Bruce Kidd, "Muscular Christianity," 706; Francis and Lathrop, "Children Who Drill," 63-64. Morrow and Wamsley, Sport in Canada, 181; Knowles, "By the Mouth of Many Messengers," 174.

27 Kidd, "Muscular Christianity," 701.

28 Janice Forsyth, "Bodies of Meaning: Sports and Games at Canadian Residential Schools," in Aboriginal Peoples and Sport in Canada: Historical Foundations and Contemporary Issues, ed. Janice Forsyth and Audrey Giles (Vancouver: UBC Press, 2013), 21-25.

29 Francis and Lathrop, "Children Who Drill," 61-80; D. Morrow, "The Strathcona Trust in Ontario, 1911-1939," Canadian Journal of the History of Sport and Physical Education 8, no. 1 (1977): 72; Frank Cosentino and Maxwell Howell, A History of Physical Education in Canada (Toronto: General Publishing Company, 1971), 44-45; Morrow and Wamsley, Sport in Canada, 180-190.

30 Janice Forsyth and Michael Heine, "A Higher Degree of Social Organization': Jan Eisendardt and Canadian Aboriginal Sport Policy in the 1950s," Journal of Sport History 35, no. 2 (2008): 262.

31 Janice Forsyth, "The Indian Act and the (Re)Shaping of Canadian Aboriginal Sport Practices," International Journal of Canadian Studies 35 (2007): 101-104; Forsyth, "Bodies of Meaning," 21-25. Forsyth notes the importance of citizenship, but further research is needed to extend this point by examining more precisely what citizenship meant to residential school administrators, how it was used in physical education, and how it changed over time.

32 Porter, "The Anglican Church and Native Education," 117-120.

33 General Synod Archives of the Anglican Church (GS), 75-103, Box 131, File 5, IRSC, "An Outline of the Duties of Those Who Occupy Positions on the Staff at the Society's Indian Residential Schools, No. III, The Teacher," no date.

34 Victoria Parashcak, "Reasonable Amusements: Connecting the Strands of Physical Culture in Native Lives," Sport History Review 29, no. 1 (May 1998): 121-22; Forsyth, "Indian Act," 98-100.

35 Department of Indian Affairs, Annual Report (Ottawa: Dominion of Canada, 1926), 16.

36 Department of Indian Affairs, Annual Report, (Ottawa: Dominion of Canada, 1938), 191.

37 GS, 75-103, Box 131, File 5, IERSC, "An Outline of the Duties of Those Who Occupy Positions on the Staff at the Society's Indian Residential Schools, No. IV, The Boys Supervisor," no date. Library and Archives Canada (LAC), Record Group (RG) 10,Volume 6215, File 470-5, Part 4, letter from T. B. R. Westgate to R. A. Hoey, September 24, 1940.

38 Department of Indian Affairs, Daily Register for Recording the Attendance of Indian School Pupils (Ottawa: Government Printing Bureau, 1923).

39 Ibid. The focus on the chest and neck were intended to promote respiratory health.

40 Department of Indian Affairs, Calisthenics and Games, Prepared for Use in All Indian Schools (Ottawa: Government Printing Bureau, 1910). This booklet provides some 
philosophical underpinnings of physical activity and provides detailed descriptions for thirty-one calisthenics exercises along with descriptions for nine games. The degree to which teachers used this resource is not known.

41 Ibid., 7.

42 Department of Indian Affairs, Annual Report (Ottawa: Dominion of Canada, 1932), 11 .

43 Department of Indian Affairs, Annual Report (Ottawa: Dominion of Canada, 1936), 21.

44 Kelm, Colonizing Bodies, 62-3.

45 Milloy, A National Crime, 77-108.

46 Churchill, Kill the Indian, 29-44. Student complaints of hunger pains was a feature of life at Pelican Lake School, but complaints were dealt with through sadistic measures to ensure discipline and silence, rather than being understood as having health implications. Miller, Shingwauk's Vision, 294-295.

47 TRC, Canada's Residential Schools: The History. Part 1: Origins to 1939. Vol. 1 of The Final Report of the Truth and Reconciliation Commission of Canada (Montreal and Kingston: McGill-Queen's University Press, 2015), 377.

48 Ibid., 394-396.

49 Ibid., 396.

50 Ibid., 396.

51 Department of Indian Affairs, Calisthenics and Games, 5.

52 The use of recreation in Anglican schools was designed to promote discipline, team spirit, and patriotism. Barman, "Sports and the Development of Character," 242; Knowles, "By the Mouth of Many Messengers," 174.

53 GS, 75-103, Box 131, File 5, IERSC, "An Outline of the Duties of Those Who Occupy Positions on the Staff at the Society's Indian Residential Schools, No. III, The Teacher," no date.

54 Department of Indian Affairs, Daily Register.

55 Department of Indian Affairs, Calisthenics and Games, 17.

56 Miller, Shingwauk's Vision, 217-250; Forsyth, "Indian Act," 103-104.

57 Miller, Shingwauk's Vision, 217-218.

58 Ibid.

59 Ibid.

60 Donald Auger, Indian Residential Schools in Ontario (Nishnawbe Aski Nation, ON: Nishnawbe Aski Nation, 2005), 93.

61 GS, 75-103, Box 23, T. B. R. Westgate, "Report of the Field Secretary MSCC [Missionary Society of the Church of England in Canada], on his visit to the Sioux Lookout and Chapleau Schools, Ottawa, Port Hope, Toronto, and Other Centres," July 1927.

62 Lawrence Baxter, a former Pelican Lake School student, spoke of his father's experiences of work rather than schooling at Pelican Lake School in the 1920s. Healing the Generations. Directed by Joe Beardy (Wolf Clan Productions), VHS.

63 Miller, Skyscrapers Hide the Heavens, 135. Residential schools, however, never became financially self-supporting entities.

64 Ibid.

65 Keewatin Diocesan Dorcas Secretary, "Report of the Dorcas Secretary Treasurer," The Living Message 37, no. 11 (1926): 349.

66 GS, 75-103, Box 23, T. B. R. Westgate, "Report of the Field Secretary MSCC, on his visit to the Sioux Lookout and Chapleau Schools, Ottawa, Port Hope, Toronto, and Other Centres" July 1927.

67 TRC, The Survivors Speak: A Report of the Truth and Reconciliation Commission (n.p., 2015), 110, http://www.trc.ca/websites/trcinstitution/File/2015/Findings/Survivors_ Speak_2015_05_30_web_o.pdf. 
68 Keewatin Diocesan Dorcas Secretary, "Report of the Dorcas Secretary Treasurer," 349.

69 GS, 75-103, Box 23, T. B. R. Westgate, "Report of the Field Secretary MSCC, on his visit to Toronto, the Shingwauk Home, the Chapleau and Sioux Lookout Schools," June 1928.

70 Keewatin Diocesan Dorcas Secretary, "In the Wilds of Western Ontario," The Living Message 39, no. 5 (1928): 148. Such a statement points to a cultural perspective that school administrators brought to play and recreation, which included the need for designated play space in order to accrue the benefits of organized and instructed lessons, rather than, for example, play in the surrounding forested areas, which would not have been seen as a legitimate way to be active and develop.

71 GS, 75-103, Box 23, File 9, Indian School Administration, Superintendent's Visit to Sioux Lookout Residential School, October 24, 1952.

72 Keewatin Diocesan Dorcas Secretary, "In the Wilds of Western Ontario," 148.

73 Keewatin Diocesan Dorcas Secretary, "Report of the Dorcas Secretary Treasurer," 349.

74 GS, 75-103, Box 131, File 4, IERSC, "The Indian and Eskimo Residential School Commission of the MSCC." The Sioux Lookout School, no date.

75 Ibid.

76 LAC, RG 10, Volume 470-5, File 6215, Part 1, letter from T. B. R. Westgate to the Secretary at the Department of Indian Affairs, July 7, 1927. This was typical of many schools that had perennial problems with buildings and maintenance. Auger, Indian Residential Schools, 21-23.

77 LAC, RG 10, Volume 470-5, File 6215, Part 2, letter from Rev. J. Marshall to the secretary at the Department of Indian Affairs, August 15, 1930.

78 Department of Indian Affairs, Calisthenics and Games, 3.

79 GS, 75-103, Box 23, T. B. R. Westgate, "Report of the Field Secretary MSCC, on his visit to the Sioux Lookout School," October 1929.

80 GS, 75-103, Box 131, File 4, IERSC, The Indian and Eskimo Residential School Commission of the MSCC. The Sioux Lookout School, no date. The MSCC notes that young children were admitted because they were orphaned and without a home.

81 Sioux Lookout and District Historical Society, Tracks Beside the Water: Book 2 (Sioux Lookout, ON: Inter-Collegiate Press, 1982), 146.

82 GS, 75-103, Box 131, File 4, IERSC, The Indian and Eskimo Residential School Commission of the MSCC. The Sioux Lookout School, no date.

83 Department of Indian Affairs, Annual Report (Ottawa: Dominion of Canada, 1932), 55; Department of Indian Affairs, Annual Report (Ottawa: Dominion of Canada, 1935), 48; Department of Indian Affairs, Annual Report (Ottawa: Dominion of Canada, 1939), 264.

84 TRC, The Survivors Speak, 52.

85 GS, 75-103, Box 131, File 4, IERSC, The Indian and Eskimo Residential School Commission of the MSCC. The Sioux Lookout School, no date.

86 Ibid.

87 Ibid.

88 Ibid.

89 Cited in Auger, Indian Residential Schools, 96. During the 1950s, the school was powered by electricity, and thus the work demands for the boys was eliminated in this area.

90 LAC, RG 10, Volume 470-5, File 6215, Part 2, letter from A. F. Mackenzie to Rev. J. Marshall, April 17, 1930.

91 Indian Affairs, Annual Report, 1931, I-32.

92 After 1932, the format was simplified in the Annual Reports and this made it impossible to record sport supplies in the school budgets; after 1939, the school budgets are not reported in Indian Affairs' Annual Reports. 
93 GS, 75-103, Box 19, Minutes of Meeting, Indian and Eskimo Residential School Commission, January 18, 1938.

94 Ibid.

95 Miller, Shingwauk's Vision, 273.

96 Keewatin Diocesan Dorcas Secretary, "Report of the Dorcas Secretary Treasurer," 384.

97 GS, 75-103, Box 131, File 4, IERSC, The Indian and Eskimo Residential School Commission of the MSCC. The Sioux Lookout School, no date.

98 For several examples, see GS 75-103, Box 131, File 1.

99 GS, 75-103, Box 131, File 4, IERSC, The Indian and Eskimo Residential School Commission of the MSCC. The Sioux Lookout School, no date.

100 Ibid.

101 Ibid.

102 Braden Te Hiwi, "Physical Culture as Citizenship Education at Pelican Lake Indian Residential School, 1926-1970” (PhD diss., University of Western Ontario, 2015), 103.

103 Ibid.

104 LAC, RG 10, Volume 6216, File 470-5, Part 6, G. Swartman, "Quarterly Report on Sioux Lookout Agency," March 1945.

105 GS, 75-103, Box 131, File 4, IERSC, The Indian and Eskimo Residential School Commission of the MSCC. The Sioux Lookout School, no date.

106 Extract from Report of J. M. Ridge to Dr. Moore, October 1, 1945, LAC, RG 10, Volume 6216, File 470-5, Part 6.

107 TRC, The Survivors Speak, 177-178;

108 GS, 103-75, Box 19, Minutes of Meeting, Indian and Eskimo Residential School Commission, September 28, 1937; GS, 103-75, Box 19, Minutes of Meeting, Indian and Eskimo Residential School Commission, October 19, 1937.

109 GS, 103-75, Box 19, Minutes of Meeting, Indian and Eskimo Residential School Commission, September 28, 1937.

110 Ibid.

111 GS, 103-75, Box 19, Minutes of Meeting, Indian and Eskimo Residential School Commission, April 6, 1937.

112 LAC, RG 10, Volume 6216, File 470-23, Part 1, Memorandum of an Inquiry to the Cause and Circumstances of the Death of (N. N.), October 19, 1937; LAC, RG 10, Volume 6216, File 470-23, Part 1, Memorandum of an Inquiry to the Cause and Circumstances of the Death of (N. N.), October 17, 1937.

113 LAC, RG 10, Volume 6216, File 470-23, Part 1, Memorandum of an Inquiry to the Cause and Circumstances of the Death of (N. N.), January 7, 1938.

114 GS, 103-75, Box 19, Minutes of Meeting, Indian and Eskimo Residential School Commission, May 10, 1938; GS, 103-75, Box 19, Minutes of Meeting, Indian and Eskimo Residential School Commission, March 14, 1939; GS, 75-103, Box 23, File 2, "Report of the Secretary of the Commission on his Visit to the Chapleau and Sioux Lookout Schools," September 30, 1940; GS, 103-75, Box 19, Minutes of Meeting, Indian and Eskimo Residential School Commission, November 5, 1940; GS, 103-75, Box 19, Minutes of Meeting, Indian and Eskimo Residential School Commission, April 8, 1941; GS, 103-75, Box 19, Minutes of Meeting, Indian and Eskimo Residential School Commission, May 13, 1943; GS, 103-75, Box 20, File 1, Minutes of Meeting, Indian and Eskimo Residential School Commission, October 13, 1944.

115 Ken Coates, "'Betwixt and Between': The Anglican Church and the Children of the Carcross (Chooutla) Residential School, 1911-1954,” BC Quarterly 64 (Winter 1984-5): 41-47.

116 TRC, Honouring the Truth, 110-113.

117 Miller, Shingwauk's Vision, 156-157, 277. 